УДК 347.155

DOI https://doi.org/10.32837/pyuv.v0i1(30).516

\author{
H. O. Тищук \\ orcid.org/0000-0002-6068-9263 \\ аспірант кафедри цивільного права \\ Національного університету «Одеська юридична академія»
}

\title{
«ДРІБНІ ПОБУТОВІ ПРАВОЧИНИ» ЯК ОСНОВНИЙ ВИД ПРАВОЧИНІВ, ЯКІ ВЧИНЯЮТЬ МАЛОЛІТНІ ОСОБИ
}

Постановка проблеми. Коло правочинів, які можуть бути вчинені малолітніми особами, напряму залежить від обсягу дієздатності такої особи. Відповідно до законодавства особи до 14 років є частково дієздатними, а тому може вчиняти лише невелике коло дій у межах обсягу дієздатності.

Усі правочини, які може здійснювати малолітня особа, можна поділити на: правочини, які знаходяться в межах її цивільної дієздатності та за законодавством можуть вчинятися самостійно (відповідно до ч. 1 ст. 31 ЦК України це дрібні побутові правочини); правочини, які знаходяться поза межами її цивільної дієздатності і які згодом були схвалені її батьками (усиновлювачами) або одним із них, із ким вона проживає, або опікуном (ч. 1 ст. 221 ЦК України), або ж які на вимогу заінтересованої особи були визнані судом дійсними, якщо буде встановлено, що вони вчинені на користь малолітньої особи (ч. 2 ст. 221 ЦК України). Також зазначені особи можуть здійснювати особисті немайнові права на результати інтелектуальної, творчої діяльності, що охороняються законом.

Окремого наукового аналізу потребують питання розуміння категорії «дрібний побутовий правочин», зарахування правочинів, які реально вчиняються малолітніми особами до зазначеної категорії, встановлення відповідності віку особи вчинених малолітньою особою правочинів «дрібним побутовим».

Оцінка стану літератури. Дослідженню питань вчинення правочинів фізичними особами відповідно до обсягу дієздатності приділяли увагу такі вчені, як Т.В. Водоп'ян, Ю.А. Дербакова, І.В. Давидова, О.С. Іоффе, Н.С. Кузнецова, В.В. Луць, Р.А. Майданик, М.В. Міщенко, Є.О. Харитонов, В.П. Шахматов та ін. Разом із тим особливостям вчинення малолітніми особами дрібних побутових правочинів відповідно до їх віку окрема увага не приділялася.

Метою статті є аналіз категорії «дрібний побутовий правочин», проблеми зарахування правочинів, які реально вчиняються малолітніми особами, до зазначеної категорії, встановлення відповідності вчинених малолітньою особою правочинів до «дрібних побутових» віку особи.

Виклад основного матеріалу. Дрібним побутовим $є$ такий правочин, який задовольняє побутові потреби особи, відповідає її фізичному, духовному чи соціальному розвитку та стосується предмета, який має невисоку вартість [1]. Важливо, щоб зазначені ознаки характеризували цей правочин у сукупності.

У літературі робиться акцент на тому, що такий правочин (дрібний побутовий) має повністю виконуватися сторонами в момент його вчинення, а тому він може вчинятися або усно (ч. 1 ст. 205 ЦК України), або шляхом здійснення конклюдентних дій (ч. 2 ст. 205 ЦК України) [2; 3, с. 100].

Сам термін «побут» у словнику тлумачиться як «повсякденне життя» [4]. Зарахування до поняття «побуту» таких категорій, як харчування, одяг, місце проживання, власна безпека, навчання тощо, не викликає сумнівів. Однак чи належить, наприклад, позашкільне навчання до цієї категорії, не зрозуміло. Тим більше, що дитині від 0 до 14 років залежно від їі конкретного віку необхідні різні побутові речі, куди може належати i необхідність у позашкільному навчанні.

Однією з ознак дійсності правочину є відповідність волі волевиявленню, що буде справедливим і стосовно малолітніх осіб, адже вони так само можуть мати внутрішню волю, яка є регуляційним процесом і спрямовує діяльність на досягнення майбутнього результату [5, с. 131]. Разом із тим внаслідок недостатнього психологічного розвитку волевиявлення може не відповідати волі, або ж навіть при їх відповідності можуть бути не враховані інші критерії, наприклад, ризик, можливість помилки, введення в оману тощо.

Схожу точку зору висловлює і Ж.Л. Чорна, яка зазначає, що бажання та прагнення малолітньої особи придбати відповідну річ (наприклад, іграшку) свідчить про наявність у неї такої волі. Проте щоб виражена особою воля породила цивільні права та обов'язки, необхідно, щоб вона могла повною мірою усвідомлювати значення своїх дій та (або) керувати ними [6, с. 113]. Отже, воля може набути юридичного значення за умови усвідомлення значення своїх дій та змоги ними керувати [7, с. 125].

Не можна не погодитися з В.А. Бєловим, який звертає увагу на те, що на практиці малолітніми особами вчиняється велика кількість правочинів, таких як купівля-продаж продуктів у підприємств роздрібної торгівлі, міни, отримання і 
дарування подарунків (вартість яких не завжди дає змогу зарахувати такий правочин до категорії дрібних побутових), отримання та передача іграшок у безоплатне користування. А відсутність позовів про застосування наслідків недійсності зазначених правочинів свідчить на користь того, що вони визнаються дійсними [8, с. 56]. Разом із тим фактично в зазначених прикладах діють положення ст. 222 ЦК України.

Визначені в законодавстві характерні риси дрібного побутового правочину («побутові потреби», «відповідність розвитку особи», «невисока вартість») є доволі оціночними і в кожному окремому випадку можуть тлумачитися по-іншому.

На підтвердження такої позиції виступають і такі науковці, як В.I. Борисова, I.В. Спасибо-Фатєєва, В.Л. Яроцький та інші, які звертають увагу на те, що поняття дрібного побутового правочину є оціночним і у разі спору суд, виходячи з оцінки фактичних обставин справи, має кваліфікувати правочин як дрібний побутовий або як такий, що не відповідає вказаним у чинному законодавстві вимогам [9, с. 119].

Категорія «відповідність розвитку особи» включає в себе відповідність їі фізичному, духовному чи соціальному розвитку. Ця категорія є вельми суб'єктивною, буде залежати від віку дитини; традицій, яких дотримуються в кожній конкретній сім’ї, змоги сім’ї розвивати дитину. Особливо актуальними є питання згаданого вище позашкільного навчання та розвитку.

Поняття «невисока вартість» трактується кожною сім'єю по-своєму, що напряму залежить від рівня їх матеріального забезпечення [10]. Тому за умови виникнення спору питання щодо «невисокої» вартості предмета правочину, оцінювати «ступінь» фізичного, духовного та соціального розвитку малолітнього необхідно окремо в кожному конкретному випадку [11, с. 73].

Також, як і категорії «відповідність побутовим потребам» та «відповідність розвитку особи», категорія «невисока вартість» $€$ досить суб'єктивною, оскільки на їі визначення впливають різні фактори, тому визначення максимальної межі такої «невисокої» вартості буде відрізнятися (наприклад, у дітей 8, 10 та 13,5 років, мешканців міста чи села, у визначенні дитиною та її батьками тощо).

Отже, дрібні побутові правочини малолітня особа здійснює за рахунок коштів, що надані їй на ці цілі законними представниками, і досить часто вони вчиняються за присутності такого представника, що фактично свідчить про надання ним згоди на укладення відповідного правочину. Якщо ж мова йде про вчинення правочину малолітньою особою самостійно (наприклад, купування обіду в школі, канцелярських товарів або ж необхідних продуктів додому), то кошти надаються законними представниками в необхідному обсязі та на конкретні цілі, де здебільшого дорослий буде бачити результат укладеного правочину.

У цьому контексті залишається питання щодо купівлі товарів малолітньою особою, на які дорослий не погоджується і фактично не може проконтролювати (наприклад, дитині 10 років і більше), або ж покупка є шкідливою для здоров'я самої дитини (наприклад, може викликати алергічну реакцію, приступ задухи тощо), i, навіть знаючи про це, дитина через свій вік може піддатися спокусі купити заборонений товар, особливо якщо перебуває під моральним впливом однолітків, реклами або інших зовнішніх чинників. У цьому випадку товар може бути «не забороненим», відповідати традиційним нормам щодо роздрібного його продажу малолітнім особам (як, наприклад, газовані напої, чіпси тощо), однак може й бути визнаний недійсним внаслідок незгоди батьків на таку покупку та вимоги повернути його до магазину. Разом із тим відповідальність за життя та здоров'я лежить на батьках (опікунах), і у разі завдання шкоди внаслідок вживання таких товарів дитиною продавець не може бути притягнутий до відповідальності.

Ж.Л. Чорна пропонує для визначення вартості вчинюваного малолітнім правочину відштовхуватись від конкретної межі, наприклад, взяти за основу неоподаткований мінімум доходів громадян, що допоможе кожен правочин кваліфікувати як такий, що відповідає чи не відповідає ознакам «дрібного побутового» [12, с. 61].

Однак встановлення такого "прямого зв'язку» між визнанням правочину "дрібним побутовим» та неоподаткованим мінімумом доходів громадян не завжди матиме позитивний ефект, адже буде враховувати можливості конкретної сім'ї, дитини, суб'єктивних факторів, які могли мати вирішальне значення при прийнятті дитиною рішення вчинити правочин.

Л.Г. Кузнецова виділяє такі ознаки дрібного побутового правочину: 1) безпосередня спрямованість на задоволення потреб громадянина (придбання продуктів, предметів побуту та гігієни, шкільного приладдя тощо); 2) моменти укладення та виконання збігаються або слідують один за іншим; 3) незначна сума [13, с. 34-35].

M.В. Міщенко, яка називає схожі з проаналізованими вище ознаки дрібних побутових правочинів, зазначає можливі варіанти дрібних побутових правочинів: договір купівлі-продажу (передусім це договір роздрібної торгівлі та міни); договір надання послуг (наприклад, договір перевезення громадським транспортом, послуги розважального характеру у дитячих розважальних центрах, атракціонах тощо); договір дарування (коли малолітній є обдарованою особою); інші види договорів, які підпадають під поняття «дрібний побутовий правочин» (які не передбачені актами цивільного 
законодавства, але відповідають загальним засадам цивільного законодавства) [14, с. 140]. Також авторка зазначає, що зарахувати вказані договори до дрібних побутових правочинів можна лише в разі їх вчинення в усній формі.

Разом із тим нині коло перелічених правочинів на практиці є ширшим, що пов'язано, зокрема, 3 розвитком суспільства, інформаційних технологій, «дорослішанням» дітей раніше 14-річного віку (особливо якщо йдеться про використання технологій). Тому виникає питання й щодо зарахування вчинених малолітньою особою правочинів до дрібних побутових, наприклад, за умови їх укладення через мережу Інтернет. Враховуючи, що електронні правочини в основній своїй масі визнаються письмовими, а дрібні побутові - це усні (або ж конклюдентні дії). Однак замовлення товарів першої необхідності, зокрема, продуктів харчування, через інтернет-магазини чи службу доставки - це дрібний побутовий правочин «по суті», але це і не усний правочин.

Висновки. Аналіз категорії «дрібний побутовий правочин» дав змогу виділити його основні характеристики, а саме: «побутові потреби», «відповідність розвитку особи», «невисока вартість». Кожна з цих категорій має тлумачитися окремо для кожної ситуації. Не можна говорити про єдині вимоги (рівень) «побітових потреб» чи «відповідності розвитку особи» для дитини чотирьох, восьми, дванадцяти років, так само як і категорія «невисока вартість» не є універсальною і має співвідноситись із доходом конкретної родини, а тому в кожному окремому випадку допустимий максимальний розмір грошового еквіваленту правочину має встановлюватись окремо.

Перелік «побутових потреб» також напряму залежить від розвитку суспільства, а отже, 3 часом розширюється. Наприклад, нині до побутових потреб можна зарахувати оплату послуг інтернет-провайдерів, мобільних операторів, купівлю та оплату товарів і послуг за допомогою інтернет-магазинів тощо. Перелічені правочини вчиняють малолітні як сторона такого правочину. Також є група правочинів, які вчиняються не самими малолітніми особами, проте на їх користь (малолітня особа є вигодонабувачем). До правочинів можна зарахувати договір банківського вкладу, договір про страхування на користь третьої особи, договір про управління майном, договір купівлі-продажу нерухомості, інші види правочинів, які не передбачені актами цивільного законодавства, але відповідають загальним засадам цивільного законодавства.

\section{Jimepamypa}

1. Цивільний кодекс України від 16.01.2003 p. URL: https://zakon.rada.gov.ua/laws/show/435-15

2. Цивільний кодекс України : науково-практ. комент.: пояснення, тлумачення, рекомендації з викори- стання позицій вищих судових інстанцій Міністерства юстиції, науковців, фахівців: правникам, нотарям, адвокатам, суддям, викладачам, студентам. Харків : Страйк, 2009. Т. 2 : Фізична особа, 2009. 296 с.

3. Заїка Ю.О. Українське цивільне право : навч. посібник. Київ : Істина, 2005. 312 с.

4. Словник української мови: в 11 томах. Том 6, 1975. URL: http://sum.in.ua/s/pobut

5. Еникеев М.И. Основи общей и юридической психологи : учебник. Москва : Юристь, 1996. $631 \mathrm{c.}$

6. Чорна Ж⿱.Л. Вчинення правочину малолітньою особою за межами її цивільної дієздатності як підстава його недійсності. Українські наукові записки. 2016. № 57. С. 110-117.

7. Веберс Я.Р. Правосубьектность граждан в советском гражданском и семейном праве. Рига : Зинатне, 1976. $231 \mathrm{c}$.

8. Белов В.А. Занимательная цивилистика: Вопросы гражданской правосубъектности и абсолютных субъективных гражданских прав. Законодательство. 2003. № 6. С. 54-59.

9. Цивільне право : підручник: у 2 т. / за ред В.І. Борисової, І.В. Спасибо-Фатєєвої, В.Л. Яроцького. Харків : Право, 2012. Т. 1.656 с.

10. Водоп'ян Т.В. Особливості дієздатності малолітніх у цивільному праві України. Часопис Національно20 університету «Острозька академія». 2013. № 2(8). Режим доступу: http://lj.oa.edu.ua/articles/2013/n2/ 13vtvtpu.pdf.

11. Бірюков І.А., Заїка Ю.О. Цивільне право України. Загальна частина : навч. посібник. Київ : КНТ, $2006.480 \mathrm{c}$.

12. Чорна Ж.Л. Особливості дієздатності малолітніх і неповнолітніх осіб за цивільним законодавством України, Росії, Білорусі. Університетські наукові записки. 2010. № 3(35). С. 60-64.

13. Кузнецова Л.Г., Шевченко Я.Н. Гражданско-правовое положение несовершеннолетних. Москва : Юрид. лит., 1968. 136 с.

14. Міщенко М.В. Характеристика та види правочинів за участю малолітніх осіб. Науковий вісник Ужгородського національного університету. 2015. Вип. 33. Т. 1. С. 138-141.

\section{Анотація}

Тищук Н. О. "Дрібні побутові правочини" як основний вид правочинів, які вчиняють малолітні особи. - Стаття.

У статті здійснено аналіз категорії «дрібний побутовий правочин», проблем зарахування правочинів, які реально вчиняються малолітніми особами, до зазначеної категорії; встановлено відповідності віку особи вчинених малолітньою особою правочинів «дрібним побутовим».

Встановлено, що визначені в законодавстві характерні риси дрібного побутового правочину («побутові потреби», «відповідність розвитку особи», «невисока вартість») є доволі оціночними і в кожному окремому випадку можуть тлумачитися по-іншому. Не можна говорити про єдині вимоги (рівень) «побітових потреб» чи «відповідності розвитку особи» для дитини чотирьох, восьми, дванадцяти років, так само як і категорія «невисока вартість» не є універсальною і має співвідноситись із доходом конкретної родини, а тому в кожному окремому випадку допустимий максимальний розмір грошового еквіваленту правочину має встановлюватись окремо.

Дрібні побутові правочини малолітня особа здійснює за рахунок коштів, що надані їй на ці цілі закон- 
ними представниками, і досить часто вони вчиняються за присутності такого представника, що фактично свідчить про надання ним згоди на укладення відповідного правочину. Якщо ж мова йде про вчинення правочину малолітньою особою самостійно (наприклад, купування обіду в школі, канцелярських товарів, або ж необхідних продуктів до дому), то кошти надаються законними представниками в необхідному обсязі та на конкретні цілі, де здебільшого дорослий буде бачити результат укладеного правочину.

Перелік «побутових потреб» також напряму залежить від розвитку суспільства, а отже, з часом розширюється. Нині до побутових потреб можна зарахувати оплату послуг інтернет-провайдерів, мобільних операторів, купівлю та оплату товарів і послуг за допомогою інтернет-магазинів тощо. Перелічені правочини вчиняють малолітні як сторона такого правочину. Також є група правочинів, які вчиняються не самими малолітніми особами, проте на їх користь (малолітня особа є вигодо набувачем). До правочинів можна зарахувати договір банківського вкладу, договір про страхування на користь третьої особи, договір про управління майном, договір купівлі-продажу нерухомості, інші види правочинів, які не передбачені актами цивільного законодавства, але відповідають загальним засадам цивільного законодавства.

Ключові слова: правочин, дрібний побутовий правочин, малолітня особа, дієздатність.

\section{Summary}

Tyshchuk N. O. "Small household transactions" as the main type of transactions committed by minors. Article.

The article analyzes the category of "small household transactions", problems of attribution of transactions that are actually committed by minors to the specified category; the juvenile person's correspondence with the "minor household" age of the person was established.
It is established that the characteristic features of the small household transaction defined in the legislation ("household needs", "correspondence of development of the person", "low cost") are rather evaluative and in each case can be interpreted differently. It is not possible to talk about the single requirements (level) of "household needs" or "suitability of development of a person" for a child of four, eight, twelve years, as well as the category "low cost" is not universal and should be related to the income of a particular family, and therefore in each case, the allowable maximum amount of the cash equivalent transaction must be set separately.

Minor household transactions are carried out by a minor at the expense of the legal representatives provided to them for these purposes, and quite often they are made in the presence of such a representative, which in fact testifies to their consent to conclude the relevant transaction. When it comes to making a deal on a minor by yourself (for example, buying lunch at school, stationery, or necessary products at home), the funds are provided by legal representatives to the extent necessary and specific goals, where in most cases the adult will see the result of the prisoner deal.

The list of "household needs" is also directly dependent on the development of society, and therefore over time - it expands. Today, household needs include payment for the services of Internet service providers, mobile operators, purchase and payment for goods and services through online stores and more. These transactions are committed by minors as a party to such transaction. There is also a group of transactions that are committed not by the minors themselves, but in their favor (the minor is a beneficial acquirer). The actions include: a bank deposit agreement; a third-party insurance contract; property management agreement; real estate purchase and sale agreement; other types of transactions that are not provided for by the laws of civil law, but comply with the general principles of civil law.

Key words: legal transaction, small household transaction, minor, legal capacity. 